\title{
The Impact of Internship on the Employability of Business Management Graduates: the Indian context
}

\author{
NEENA PC
}

\begin{abstract}
The Business Management Graduates who undertake internship training are empowered to transform into a job meritoriously sooner than those who don't pursue it earnestly. The internship is a channel to prove to the future employer of his or her KSA (knowledge, skills and abilities) along with their behavioral aspects and thereby a platform to exhibit the graduate's potential to perform in a job. In this empirical learning, the author explored the feasibility of the graduates' internship outcomes which are 'conversion to job' and the 'confidence level' gained which gives an edge in the career domain. The study had examined the student's internship experience and its impact to expedite the predicted outcomes of the internship program. This article also investigates the student's perceptions of the significance of the internship in terms of the confidence built in the intern to attain a job and the added benefits augmented out of it. The predicted outcomes of the internship program are analyzed with the help of correlation and regression analysis. The results show a strong statistical correlation between conversion to a job and the attained skills through internship such as 'decision making', 'potential to manage', 'experiential learning' etc. The findings also provide a basis for evaluating the importance of a successful internship program in business management education. The results of the analysis indicated that the improvement in the graduates' attributes is dissimilar with three paths of acquiring the entry into internship viz., 'through institution', 'through candidate reference and the self-initiated internship.
\end{abstract}

Index Terms: Internship, Business Management Graduate employability, Experiential learning.

\section{INTRODUCTION}

In India, The Internship is a prerequisite in Business Management studies as a part of the core curriculum and it is a course where a graduate should get exposure to the real-time business world, hence it has gained momentum in the last years in the graduate's successful academic outcome. The graduates opting for internship are high compared to the opportunities available, there is a chance that many of the applicants are not able to find firms and should opt for freelance as the demand is greater than the supply. The major corporates such as Amazon, ITC and MNC Banks hire interns as it provides the ideal channel for the companies to have an insight into the potential employees to be recruited. There is substantial evidence that the internships advance the aspirant to get into better employment.

Revised Manuscript Received on October 25, 2019

Neena PC, Management Dept, Christ Deemed to be University, Institute of Management, Pune, India.neena.pc@christuniversity.in

\section{LITERATURE REVIEW}

\section{A. Internship}

An internship is an interim prospect for students to work (paid or unpaid) for an employer with an opportunity to get exposure to experiential learning of the academics [1]. The theoretical aspects which the students learn from the academics are applied to real-world scenario and thereby learning to execute tasks which will be useful for future jobs. There is a different way of classification of this work-based programs as per the course has undergone such as internships, co-ops, apprenticeships, SIP (summer internship programs), OJT (On the Job Training), projects and practicums. This distinction can be based on the course structure and pedagogy a student is enrolled. Internships are practical exposure which is intended to do at the end of a professional program supported by a supervisor [2].

\section{B. Internship for Business Management graduates'}

The management graduates' who had done internship diligently [3] are more likely to be employable sooner than those who have just done for it for the sake of completion of the course. The internship enables the student to pursue a job easier and improves his skills which leads to the satisfaction [4] of the outcome of the professional course enrolled. The most general internships are offered in various employment sectors which are offered for MBA graduates is in private sector followed by non-profit groups, freelance, project study in companies and organizational study.

\section{Gateway to the Job world}

The internship has a substantial impact on the graduate's conversion to job [5] as it is also considered as work-integrated learning experience [6]. The institutes which had opted internship as part of their curriculum consider it strictly for the realization of its benefits for their student's future [7]. From the Employer's perspective, it enables them to choose first-class students upon graduation [8]. The employers, as well as the students, gain advantage from an organized internship which increases the satisfaction level of the students. Narayanan et.al., [9] states that there is a correlation between the satisfaction rating of the graduates and the choice in the activity they perform as an intern.

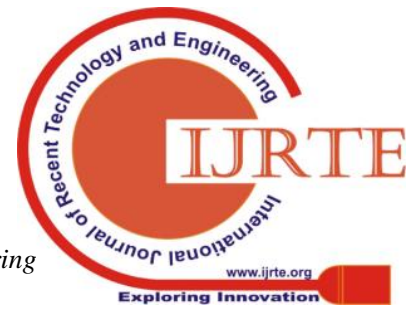


Many of the graduates had given positive feedback on the outcome of the internship [10] with the evaluation conducted to analyze its impact on the graduates'.

\section{Summer Internship Program (SIP) of PGDM and} MBA programs

In India, the course structure instructed by AICTE (Aicte-India.org, model curriculum for management program, January 2018) [11] for the PGDM and MBA programs include a mandatory internship with an organization, emphasize of eight weeks duration, and therefore to submit a project report that will be evaluated to grade, the student's practical knowledge gained. It aids graduates to strengthen their pre-placement offer (PPO) with the training they undergo in firms as project study, by means of the fieldwork or organizational study which is a part of pedagogy. The graduates' project reports are evaluated and assessed as part of their assessment combined with overall grades. The score allotted is high for an internship out of all the other subjects, students, also want to contribute significantly, but the drawback is in the entry of the graduates to many of corporate firms.

\section{E. Firm's Viewpoint}

It can be due to the reason that the firms don't want to share the organization's data, especially financial data which seem to be confidential. The other could be there is no space for them to accommodate interns in the organization due to the hectic routine schedule. There may be several other reasons which demand an employee of the firm, who should dedicate time to supervise the interns, which leads to a fall in his output and this is another constrain for training the interns. The internship is successful in the Corporates' where there is a dedicated system to conduct it in a systematic manner [12] The summer placements offer the perfect platform for companies to size up potential employees during their internship stint, which results in an informed decision and judgement about the candidates.

\section{F. Internship Benefits}

- The internship helps employers to identify the potential employees as there is a direct interaction among the intern and company employees which is a boon for the employer to emphasize on the successful recruitment of the right candidate for the future vacancy or existing vacancy.

- The other advantage of the internship for a firm is that they can save the cost of recruitment to hire fresher from institutions. The campus recruitment is conducted as a huge process with automated tests for a large number of candidates and the selection involves various sequences of steps such as written test, Group discussion, and HR interview. And in the short time of HR interview, the behavioral aspects of the person cannot be judged which may end up in a wrong selection at the cost of the recruitment, whereas the traits of an intern can be studied in the short term duration in the firm, which is the positive aspect of recruiting an intern for a job in the same organization.

- There are benefits to both sides as the intern were given an opportunity to perform in the firm, which in turn is a gain for the employer to evaluate the graduate's efficacy. The internships improve students' employability, helps them to identify the skill gap and thereby assist to overcome the shortages before stepping into a real career world. Some of the graduates even suggested that it enabled them for career choice, and to identify their own unknown potential hidden talent.

- The other group of interns remarked that the internship didn't benefit them much as they claim that they didn't gain much confidence. It may be due to the reasons that they were not given proper mentoring with the supervision from the firm side and were not given the domain based significant training, and thereby ends with less satisfaction.

\section{THEORETICAL FRAMEWORK FOR THE STUDY}

There are many variables affecting the internship's outcome in the employability of management graduates. In this study, the framework has been developed to study the impact of internship as a gateway towards five employability projections which enable the graduate to step into a firm easily. The theoretical framework of this study is developed based on the supporting theory by David Kolb (2002).[13] The analysis of the study is conducted on five parameters of which 'conversion to job is the dependent variable and the 'confidence level' gained through internship', 'experiential learning', 'potential to manage' and 'decision making' are as independent variables. The fundamental theory of Kolb's experiential learning emphasizes that an individual should get exposure to the practical aspects of learning and that an individual should reflect on his experience in all the stages of the learning cycle.

\section{RESEARCH METHODOLOGY}

The five elements of Kolb's experiential learning are taken to analyze the factors for the conversion of internship to a job. The contemporary studies on the conversion of internship to a job are also analyzed. The respondents of this research are the fresh graduates who had undergone internships in different firms. The graduates were in the final semester of their professional course in which internship is a mandatory part of their academic curriculum.

A structured questionnaire was used to collect data and it was validated using test and retest (multiple pilot studies) to ensure that the respondents respond to the questions effectively. The reliability was also assessed. The data was collected through an interview as well as through online google forms and 147 completed responses were taken for analysis.

Published By: 
The five-point Likert scale was used for grading the responses and the pilot study was conducted among 50 students from two institutes in Bangalore to validate the instrument. The Cronbach alpha, Cohen's kappa and Pearson Chi-square were used to analyze the validity and reliability of the data. The students were asked to give their opinion of value from 1 through 5 on a Likert scale, where $5=$ confidence gained is very high, $4=$ confidence gained is high, 3 = confidence gained medium, and $2=$ less confidence gained and $1=$ no change in confidence.

The Cronbach alpha shows the reliability of the data, while Cohen's kappa measures the agreement of data or the level of the respondent understood the concept or research problem. The Chi-square is a measure of the dependency of dependent variable on the independent. In this analysis, Cronbach alpha is 0.893(table 1.1) which shows high reliability. Cohen's kappa and Chi square were estimated using the cross tab of descriptive variables of the respondents. The Cohen's kappa was more than 0.6 and statistically significant while the Phi value was more than 0.5 . Hence, the data is moderately independent and reliable. A Paired t-test was conducted to test whether the responses are similar or from the same group of responses.

Table 1.1. Reliability Statistics

\begin{tabular}{|c|c|c|}
\hline $\begin{array}{c}\text { Cronbach's } \\
\text { Alpha }\end{array}$ & $\begin{array}{c}\text { Cronbach's Alpha Based on } \\
\text { Standardized Items }\end{array}$ & $\begin{array}{c}\text { No: of } \\
\text { Items }\end{array}$ \\
\hline .893 & .897 & 5 \\
\hline
\end{tabular}

The key rationale of this study was to examine the type of student's internship occurrence based on the variable 'conversion to job'(CJ) and the key independent variable such as the 'confidence level (CL)gained through internship'. The students were asked to rate their internship experience based on the parameters such as the decision-making (DM), experiential learning (EL) and potential to manage (PM). The internship which classified as 'internship by self', (freelance) doesn't give much exposure to experiential learning as there is no 'On the job training' and have lots of constraints for the intern to access data direct from the company. The student's confidence built through the internship is directly related to the decision-making capability achieved, potential to manage the situations and the level of experiential learning which had attained. The main criteria are taken as 'confidence level' gained by the graduates. The mean of the confidence gained is ' 3.31 ', higher out of all other parameters which indicates that students generally perceived that the confidence they had gained of their internship experience as highly relevant.

The factor analysis is conducted to eliminate the unrelated variable and to group based on their correlations. To estimate the sampling adequacy and Sphericity the KMO factor value and Bartlett's Test value were considered. KMO value is .866 \& Bartlett's Test of Sphericity Chi-Square value is 391.408 and it is statistically significant. Seventeen variables reduced to twelve variables and grouped in to five groups based on the Eigen values. The groups having Eigen values more than or

equal to 1 is taken. As in the factor analysis, the Kaiser-Meyer-Olkin Measure of Sampling Adequacy is $86 \%$ (.866) and chi-square is 391.408 which confirms the internal consistency of data.

\section{RESULTS AND DISCUSSIONS}

From the regression model summary in table 1.2, the regression co-efficient and ' $\mathrm{r}$ ' are high for internship through institution and the ' $\mathrm{f}$ ' change is high for internship through reference. This supports above explanation for the variation of skills among students who have undergone different types of internship. The regression model explained $43.7 \%$ variation in conversion to employability with the variation in independent variables.

Table 1.2 Model summary

\begin{tabular}{|c|c|c|c|c|c|c|c|c|}
\hline \multirow[b]{2}{*}{$\begin{array}{c}\text { MODEL } \\
\mathrm{S} \\
\end{array}$} & \multirow[b]{2}{*}{$\mathrm{R}$} & \multirow[b]{2}{*}{$\begin{array}{c}\mathrm{R} \\
\mathrm{SQU} \\
\mathrm{ARE}\end{array}$} & \multirow[b]{2}{*}{$\begin{array}{c}\text { STD. } \\
\text { ERROR } \\
\text { OF THE } \\
\text { ESTIM } \\
\text { ATE } \\
\end{array}$} & \multicolumn{5}{|c|}{ CHANGE STATISTICS } \\
\hline & & & & $\begin{array}{c}\mathrm{R} \\
\mathrm{SQU} \\
\mathrm{ARE} \\
\mathrm{CHA} \\
\mathrm{NGE} \\
\end{array}$ & $\begin{array}{c}\mathrm{F} \\
\mathrm{CHA} \\
\text { NGE } \\
\end{array}$ & $\begin{array}{l}\mathrm{D} \\
\mathrm{F} \\
1 \\
\end{array}$ & $\begin{array}{c}\text { DF } \\
2 \\
\end{array}$ & $\begin{array}{c}\text { SIG. } \\
\mathrm{F} \\
\mathrm{CHA} \\
\mathrm{NGE} \\
\end{array}$ \\
\hline I-I & $\begin{array}{c}0.6 \\
61\end{array}$ & $\begin{array}{c}0.43 \\
7\end{array}$ & 0.849 & $\begin{array}{c}0.43 \\
7\end{array}$ & $\begin{array}{c}2.91 \\
1\end{array}$ & 4 & 15 & 0.05 \\
\hline I-R & $\begin{array}{c}0.6 \\
47 \\
\end{array}$ & $\begin{array}{c}0.41 \\
8\end{array}$ & 0.713 & $\begin{array}{c}0.41 \\
8 \\
\end{array}$ & $\begin{array}{c}4.31 \\
7 \\
\end{array}$ & 4 & 24 & $\begin{array}{c}0.00 \\
9\end{array}$ \\
\hline I-S & $\begin{array}{l}0.6 \\
45\end{array}$ & .416 & .871 & .416 & $\begin{array}{c}3.56 \\
0\end{array}$ & 4 & 20 & .024 \\
\hline \multicolumn{9}{|c|}{ I-I Internship Through Institution } \\
\hline I-S - I & tern & $p$ by & & & & & & \\
\hline
\end{tabular}

Table 1.3 Anova

\begin{tabular}{|c|c|c|c|c|c|c|}
\hline & & $\begin{array}{l}\text { Sum of } \\
\text { Square }\end{array}$ & df & $\begin{array}{l}\text { Mean } \\
\text { Squar }\end{array}$ & $\mathbf{F}$ & Sig \\
\hline \multicolumn{2}{|c|}{ Between People } & 534.985 & 119 & 4.496 & & \\
\hline \multirow[t]{3}{*}{$\begin{array}{l}\text { Within } \\
\text { People }\end{array}$} & $\begin{array}{l}\text { Betwee } \\
\text { n Items }\end{array}$ & 124.577 & 4 & 31.144 & 64.617 & .000 \\
\hline & $\begin{array}{l}\text { Residu } \\
\text { al }\end{array}$ & 229.423 & 476 & .482 & & \\
\hline & Total & 354.000 & 480 & .738 & & \\
\hline \multicolumn{2}{|l|}{ Total } & 888.985 & 599 & 1.484 & & \\
\hline \multicolumn{6}{|c|}{ Grand Mean $=3.01$} & \\
\hline
\end{tabular}


The Anova is '64.617' (Table 1.3) shows that the mean of all data is different or the response to each question by each student is independent and unbiased. In the analysis, the results of multiple linear regression with respect to 'internship offered by institution', the mean of respondents 'is high in between ' 3 ' and ' 4 '. It shows that students who have undergone internship for institution had gained an exposure which is above average. However, all ' $t$ ' values are statistically insignificant ( $p>.05)$, this shows that there is no difference in exposure among the students in the internship gained through institution.

Table 1.4: mean and standard deviation of responses

\begin{tabular}{|c|c|c|c|c|c|c|}
\hline \multirow[b]{2}{*}{$\begin{array}{l}\text { Kariable } \\
\text { Type of } \\
\text { internship }\end{array}$} & \multicolumn{2}{|c|}{ Institution } & \multicolumn{2}{|c|}{ Reference } & \multicolumn{2}{|l|}{ Self } \\
\hline & $\begin{array}{l}\text { Mea } \\
\text { n }\end{array}$ & $\begin{array}{l}\text { Std. } \\
\text { Dev }\end{array}$ & $\begin{array}{l}\text { Mea } \\
\text { n }\end{array}$ & $\begin{array}{l}\text { Std. } \\
\text { Dev }\end{array}$ & $\begin{array}{l}\text { Mea } \\
\text { n }\end{array}$ & $\begin{array}{l}\text { Std. } \\
\text { Dev }\end{array}$ \\
\hline $\begin{array}{l}\text { Conversion } \\
\text { to Job }(\mathrm{CJ})\end{array}$ & 3.12 & 1.2 & 2.5 & 1.3 & 2.24 & 1.6 \\
\hline $\begin{array}{l}\text { Confidence } \\
\text { Level (CL) }\end{array}$ & 3.97 & 0.8 & 3.4 & 1.1 & 3.2 & 1.3 \\
\hline $\begin{array}{l}\text { Experiential } \\
\text { Learning } \\
\text { (EL) }\end{array}$ & 3.90 & 0.9 & 3.2 & 1.2 & 3.3 & $\begin{array}{l}1.2 \\
8\end{array}$ \\
\hline $\begin{array}{l}\text { Decision } \\
\text { Making } \\
(\mathrm{DM})\end{array}$ & 3.86 & 1.0 & 3.36 & $\begin{array}{l}1.1 \\
6\end{array}$ & 3.5 & $\begin{array}{l}1.3 \\
1\end{array}$ \\
\hline $\begin{array}{l}\text { Potential to } \\
\text { Manage } \\
\text { (PM) }\end{array}$ & 3.79 & 0.9 & 3.39 & $\begin{array}{l}1.1 \\
9\end{array}$ & 3.46 & $\begin{array}{l}1.2 \\
6\end{array}$ \\
\hline
\end{tabular}

The means of factors that may help to convert to job are shown in table 1.4. The factors have high mean for students who get internship through institutions and the same for students who get internship through reference and self. From the table 1.4 , it is seen that the means of all the criteria (confidence level $=3.97$, Experiential Learning $=3.90$, Manage to potential $=3.79$, Decision making $=3.86$ ) of 'internship through reference' are higher than other two modes of internship, hence this can be attributed to the fact that the graduate is able to develop more in the case of internship through reference as the acquaintance factor will be beneficial to get opportunities faster than others. In the case of 'internship through reference', the mean of conversion to job is less than ' 2.5 ', while the means for confidence level', Experiential learning', 'potential to manage' and 'Decision making' are higher and even higher than the same of internship through institution. The 'Confidence level' and 'Conversion to job' has a significant value in the internship. This shows that the conversion to job and 'confidence limit' are varying from student to student in this category.

\begin{tabular}{|c|c|c|c|c|c|c|c|c|c|c|}
\hline $\begin{array}{l}\text { Intern } \\
\text { ship } \\
\text { type }\end{array}$ & \multicolumn{5}{|c|}{$\begin{array}{l}\text { Internship through } \\
\text { Institution }\end{array}$} & \multicolumn{5}{|c|}{$\begin{array}{l}\text { Internship through } \\
\text { reference }\end{array}$} \\
\hline $\begin{array}{l}\text { Skill } \\
\text { develo } \\
\text { ped } \\
\end{array}$ & $\begin{array}{l}\mathrm{C} \\
\mathrm{L}\end{array}$ & $\begin{array}{l}\mathbf{C} \\
\mathbf{J}\end{array}$ & $\begin{array}{l}\mathbf{E} \\
\mathbf{L}\end{array}$ & $\begin{array}{l}\mathbf{M} \\
\mathbf{P}\end{array}$ & $\begin{array}{l}\mathbf{D} \\
\mathbf{M}\end{array}$ & $\begin{array}{l}\mathbf{C} \\
\mathrm{L}\end{array}$ & $\begin{array}{l}\mathbf{C} \\
\mathbf{J}\end{array}$ & $\begin{array}{l}\mathbf{E} \\
\mathbf{L}\end{array}$ & $\begin{array}{l}\mathbf{M} \\
\mathbf{P}\end{array}$ & $\begin{array}{l}\text { D } \\
\mathbf{M}\end{array}$ \\
\hline Mean & $\begin{array}{l}3 . \\
80\end{array}$ & $\begin{array}{r}2 . \\
5 \\
0\end{array}$ & $\begin{array}{r}3 . \\
55\end{array}$ & $\begin{array}{r}3 . \\
6 \\
5\end{array}$ & $\begin{array}{r}3.6 \\
5\end{array}$ & $\begin{array}{r}3 . \\
9 \\
7\end{array}$ & $\begin{array}{r}2 . \\
45\end{array}$ & $\begin{array}{r}3.9 \\
0\end{array}$ & $\begin{array}{r}3 . \\
79\end{array}$ & $\begin{array}{r}3 . \\
86\end{array}$ \\
\hline $\begin{array}{l}\text { Std. } \\
\text { Deviati } \\
\text { on }\end{array}$ & $\begin{array}{r}1 . \\
00 \\
5 \\
\end{array}$ & $\begin{array}{l}.6 \\
8 \\
8 \\
\end{array}$ & $\begin{aligned} 1 . \\
19\end{aligned}$ & $\begin{array}{l}.9 \\
3 \\
3 \\
\end{array}$ & $\begin{array}{r}1.1 \\
37\end{array}$ & $\begin{array}{l}.8 \\
6 \\
5\end{array}$ & $\begin{array}{r}.8 \\
27\end{array}$ & $\begin{array}{r}.90 \\
0\end{array}$ & $\begin{array}{r}.7 \\
74\end{array}$ & $\begin{array}{r}.7 \\
89\end{array}$ \\
\hline $\begin{array}{l}\text { Unstan } \\
\text { dardize } \\
\text { d } \\
\text { Coeffic } \\
\text { ients B }\end{array}$ & $\begin{array}{r}1 . \\
40 \\
3\end{array}$ & $\begin{array}{l}1 \\
4 \\
2\end{array}$ & $\begin{array}{r}.3 \\
27\end{array}$ & $\begin{array}{l}.0 \\
4 \\
1\end{array}$ & $\begin{array}{r}.20 \\
1\end{array}$ & $\begin{array}{r}1 . \\
8 \\
8\end{array}$ & $\begin{array}{r}.6 \\
36\end{array}$ & $\begin{array}{r}.11 \\
6\end{array}$ & $\begin{array}{r}- \\
10 \\
2\end{array}$ & $\begin{array}{r}.1 \\
18\end{array}$ \\
\hline $\begin{array}{l}\text { Std. } \\
\text { Error }\end{array}$ & $\begin{array}{r}.9 \\
11\end{array}$ & $\begin{array}{l}.4 \\
3 \\
0 \\
\end{array}$ & $\begin{array}{r}.2 \\
44\end{array}$ & $\begin{array}{l}.2 \\
3 \\
3 \\
\end{array}$ & $\begin{array}{r}.27 \\
1\end{array}$ & $\begin{array}{l}9 \\
2 \\
3 \\
\end{array}$ & $\begin{array}{r}.1 \\
77\end{array}$ & $\begin{array}{r}.15 \\
6\end{array}$ & $\begin{array}{r}.1 \\
89\end{array}$ & $\begin{array}{r}.1 \\
91\end{array}$ \\
\hline $\mathrm{t}$ & $\begin{array}{r}1 . \\
54 \\
0 \\
\end{array}$ & $\begin{array}{l}.3 \\
3 \\
0 \\
\end{array}$ & $\begin{array}{r}1 . \\
33\end{array}$ & $\begin{array}{r}.1 \\
7 \\
7 \\
\end{array}$ & $\begin{array}{r}.73 \\
9\end{array}$ & $\begin{array}{r}2 . \\
0 \\
4 \\
\end{array}$ & $\begin{array}{r}3 . \\
58\end{array}$ & $\begin{array}{r}.74 \\
1\end{array}$ & $\begin{array}{r}-. \\
54 \\
1 \\
\end{array}$ & $\begin{array}{r}.6 \\
18\end{array}$ \\
\hline Sig. & $\begin{array}{r}.1 \\
44\end{array}$ & $\begin{array}{l}.7 \\
4 \\
6 \\
\end{array}$ & $\begin{array}{r}.2 \\
01\end{array}$ & $\begin{array}{l}.8 \\
6 \\
2 \\
\end{array}$ & $\begin{array}{r}.47 \\
1\end{array}$ & $\begin{array}{l}.0 \\
4 \\
9\end{array}$ & $\begin{array}{r}.0 \\
01\end{array}$ & $\begin{array}{r}.46 \\
6\end{array}$ & $\begin{array}{r}.5 \\
93\end{array}$ & $\begin{array}{r}.5 \\
42\end{array}$ \\
\hline
\end{tabular}

In the case of 'internship attained by self' also, the mean of conversion into job is very less, mean $=2.24$, the mean of decision making and experiential learning and confidence level is less than other two categories. The ' $t$ ' value of internship attained by self is statistically insignificant as $\mathrm{p}$ is > '.05', which shows that there is no variation in the values gained in this group. The ' $t$ ' value of EL (-1.12) indicates there isn't a significant difference between the variables which are gained through internship through self and it doesn't seem to have much impact on the graduate's impact of the internship.

The ' $t$ ' value of internship attained by self is statistically insignificant as $\mathrm{p}$ is $>$ '.05', which shows that there is no variation in the values gained in this group. As the ' $p$ ' value is $>.05$ and the $t$ value is lesser than ' 2 ', this shows that there is not much impact of the variables under internship attained by self and graduates fail to get good opportunities to be accurate in the domain, as mostly 'internship attained by self concentrates on the peripheral layer only. However, the ' $p$ ' value of the variables through reference are less than <.05, which indicates that there is a higher impact of the variables on the students' outcome through the reference and it is statistically significant. Similarly, the ' $t$ ' value is $>2$ (3.589) of conversion to job, there is a more chance of that internship to be converted into job through reference and it is highly significant. 
Table 1.5 (a): Multiple linear regression

\begin{tabular}{|l|r|r|r|r|r|}
\hline $\begin{array}{l}\text { Internship } \\
\text { type }\end{array}$ & \multicolumn{5}{|c|}{ Internship by self } \\
\hline $\begin{array}{l}\text { Skill } \\
\text { developed }\end{array}$ & \multicolumn{1}{|c|}{ CL } & \multicolumn{1}{l|}{ CJ } & \multicolumn{1}{l|}{ EL } & MP & DM \\
\hline Mean & 3.60 & 2.24 & 3.44 & 3.96 & 3.52 \\
\hline $\begin{array}{l}\text { Std. Deviation } \\
\text { d Coefficients }\end{array}$ & 1.041 & .779 & 1.193 & .935 & .918 \\
\hline $\begin{array}{l}\text { Std. Error } \\
\text { t }\end{array}$ & .895 & .323 & .240 & .259 & .213 \\
\hline Sig. & .564 & 1.739 & -1.12 & 1.77 & 1.24 \\
\hline
\end{tabular}

From the regression equations, the variation in constants shows that internship through institution has more conversion to job and variation in confidence level (40.3\%) is the significant factor in in internship through institution. In the case of internship through reference. The confidence level has a moderate influence (38\%).

Table 1.6 Employability Equation

Internship through Institution, Employability $=1.896$
$+.403(\mathrm{CL})+.327(\mathrm{EL})+.041(\mathrm{MP})$
$+.201(\mathrm{DM})$
Internship through reference, Employability $=1.403+0.38$
$(\mathrm{CL})+.116(\mathrm{EL})+.102(\mathrm{MP})+.118(\mathrm{DM})$

Internship by self, Employability $=0.896+.305(\mathrm{CL})+.270$ $(\mathrm{EL})+.262(\mathrm{MP})+.266(\mathrm{DM})$

Though the conversion to job is less in the case of internship through self-reference, confidence level (30.5\%), experiential learning $(27 \%)$, management practices $(26.2 \%)$, and Decision making (26.6\%). This clearly explain that the graduates who seek internship through self-reference are independent, self-reliant. They prefer self-employment than regular employment.

Table 1.7. Correlation. **. Correlation is significant at the 0.01 level (2-tailed).

\begin{tabular}{|l|r|r|r|r|r|r|}
\hline $\begin{array}{l}\text { CORREL } \\
\text { ATIONS }\end{array}$ & $\begin{array}{c}\text { Conv } \\
\text { ersio } \\
\text { n to } \\
\text { job }\end{array}$ & $\begin{array}{c}\text { Confi } \\
\text { denc } \\
\text { e } \\
\text { level }\end{array}$ & $\begin{array}{c}\text { Expe } \\
\text { rienti } \\
\text { al }\end{array}$ & $\begin{array}{c}\text { Mana } \\
\text { ge } \\
\text { poten } \\
\text { tial }\end{array}$ & $\begin{array}{c}\text { Decis } \\
\text { ion- } \\
\text { maki } \\
\text { ng }\end{array}$ & $\begin{array}{c}\text { Intern } \\
\text { ship } \\
\text { type }\end{array}$ \\
\hline $\begin{array}{l}\text { Conversion } \\
\text { to job }\end{array}$ & 1 & $.734^{*}$ & $.673^{*}$ & $.580^{*}$ & $.634^{*}$ & $.312_{*}^{*}$ \\
\hline $\begin{array}{l}\text { Confidence } \\
\text { level }\end{array}$ & $.734^{*}$ & 1 & $.619^{*}$ & $.575^{*}$ & $.664^{*}$ & $.402_{*}^{*}$ \\
\hline $\begin{array}{l}\text { Experientia } \\
1\end{array}$ & $.673^{*}$ & $.619^{*}$ & 1 & $.593^{*}$ & $.647^{*}$ & $.364^{*}$ \\
\hline
\end{tabular}

\begin{tabular}{|l|r|r|r|r|r|r|}
\hline $\begin{array}{l}\text { Manage } \\
\text { potential }\end{array}$ & $.580^{*}$ & $.575^{*}$ & $.593^{*}$ & 1 & $.642^{*}$ & $.583^{*}$ \\
\hline $\begin{array}{l}\text { Decision } \\
\text { making }\end{array}$ & $.634^{*}$ & $.664^{*}$ & $.647^{*}$ & $.642^{*}$ & 1 & $.486^{*}$ \\
\hline $\begin{array}{l}\text { Internship } \\
\text { type }\end{array}$ & $.312^{*}$ & $.402^{*}$ & $.364^{*}$ & $.583^{*}$ & $.486^{*}$ & 1 \\
\hline
\end{tabular}

The analysis results of table 1.7 indicate the association between the variable 'conversion into job (.734) and confidence level are stronger compared to other variables. Similarly, the variable 'experiential learning' and 'conversion to job' are highly correlated as there is a strong link between experiential learning (.673) and conversion into a job. There is a higher association between internship type (.583) and manage to potential. There is the least association of 'conversion into job' (.312) with internship type as there is no significant relationship between the type of internship a graduate opts with conversion of job.

The variable 'potential to manage' is highly correlated with decision making as it implies that through internship a graduate's potential to manage independently is empowered with the strong decision-making skills. The decision making is aligned with confidence level as a graduate's confidence is boosted with the improvement in decision making.

\section{RESULT AND DISCUSSIONS}

This study had helped to determine whether the internship enhance the graduate's ability to accomplish the projected outcomes of the internship program such as the confidence gained to land up in a job with the other predicted variables.

- Majority of the graduates in the study had informed the outcome was positive to achieve a job in the domain with improvement in their abilities and knowledge to gain a job. There is less correlation with internship type and conversion into job as the value of (.312) indicates in table 1.7 , which means that the conversion into a job is a complex process with any internship type the students undergo, as the job market is crucial which depends on the economy of the state.

- As per the course structure of the syllabus of MBA, the inclusion of the project in their curriculum is mandate, hence most of the graduates' do a freelance project rather than doing an internship. The reasons they refer to not doing the internship inside the firms are that the companies don't permit for an entry due to a large pool of applicants, which proves that the supply side is higher compared to the demand of the graduates for any firm. The regression model explained $43.7 \%$ variation in conversion to employability with the variation in independent variables. 
- The internship through institutions may have a set of screening process to retain the companies for internship programs in the following years. This screening may lead to a biasing. The remaining students only get an internship through reference and self. This is evident in table 1.4.

\section{CONCLUSION AND IMPLICATIONS}

The management graduates opined that the internship definitely helped them to improve their confidence level which in turn had given an edge for the conversion into a job. The graduates suggested that the significance given to the internship in the course should be augmented further as it leads to a better professional outcome. It is therefore predominantly important that higher education regulatory bodies to commence steps to ensure the educational quality and further to improve the effectiveness of internship, so that the potential benefits of these experiences are realized for all stakeholders. The students are progressively concerned on the lookout for approaches to gain an advantage in the job market by gaining valuable experience prior to graduation.

\section{REFERENCES}

1. Hamilton, R. A. (1992). Internships are key to direct marketing program. In A. Ciofalo (Ed.), Internships: Perspectives on experiential learning (219-221). Malabar, FL: Krieger Publishing Company.

2. Sattler, P., Wiggers, R., \& Arnold, C. H. (2011). Combining workplace training with postsecondary education: The spectrum of Work-Integrated Learning (WIL) opportunities from apprenticeship to experiential learning. Canadian Apprenticeship Journal.

3. Callanan, G. and Benzing, C. (2004). Assessing the role of internships in the career-oriented employment of graduating college students. Education and Training. 46(2), 82-89.

4. D'abate, C. P., Youndt, M. A., and Wenzel, K. E. (2009). Making the most of an internship: An empirical study of internship satisfaction. Academy of Management Learning and Education. 8(4), 527-539.

5. Knouse, S. B., Tanner, J. T., \& Harris, E. W. (2008). The relationship of college internships, college performance, and subsequent job opportunity. Journal of Employment Counseling.36(1), 35-43.

6. Trede, F. (2012). Role of work-integrated learning in developing professionalism and professional identity. International Journal of Work-Integrated Learning, 13(3), 159.

7. Raymond, M.A., McNabb, D.E., and Matthaei, C.F. (1993). Preparing graduates for the workforce: The role of business education. Journal of Education for Business. 68(4), 202-206

8. Gault, J., Leach, E., and Duey, M. (2010). Effects of business internships on job marketability: the employers' perspective. Education + Training. 52(1), 76-88.

9. Narayanan, V. K., Olk, P. M., \& Fukami, C. V. (2010). Determinants of internship effectiveness: An exploratory model. Academy of Management Learning \& Education, 9(1), 61-80.

10. Georgiou, I., Zahn, C., and Meira, B. J. (2008). A systemic framework for case-based classroom experiential learning. Systems Research and Behavioral Science. 25(6), 807-819.

11. Aicte-India.org, Model Curriculum for management program (August, 2017) Available: http://engineering. careers360.com/news/aicte-launches-model-curriculum-makes-summ er-internship-mandatory-356448(January, 2018)

12. Lam, T., and Ching, L. (2007). An exploratory study of an internship program: The case of Hong Kong students. International Journal of Hospitality Management. 26(2), 336-351. Madoch, T.A. (1980). Internship Programs-Bridging the Gap. Management World. 9(9), 36.

13. Mainemelis, C., Boyatzis, R. E., \& Kolb, D. A. (2002). Learning styles and adaptive flexibility: Testing experiential learning theory. Management learning, 33(1), 5-33.

\section{AUTHORS PROFILE}

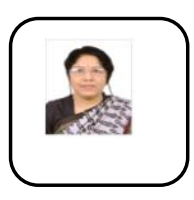

Dr. Neena. P C has been awarded doctorate from Anna University, Chennai in the field of Human Resources on the socially relevant topic "Employability of Management Graduates', a study on the Indian context within the region of three states of India. An Employability measurement tool was the outcome of the research based on Indian context with reference from Dr. Udai Pareek's Self-Assessment \& Feedback Instruments tools. Her h-index in Google scholar is 2 and has been cited by the reputed by GELO: The Global Educational Learning Observatory, Journal of University of Ontario, Institute of Technology, Canada and have publications in reputed journals of Thomson Reuters, UGC Indexed etc. She had worked with reputed B schools in Bangalore., XIME, ISBR, etc. She has 14 years of academic experience and 10 years of Corporate experience with a stint of global experience abroad in a logistics firm. The ongoing research is on the $A B C$ analysis of HR-Outsourcing and on the Block chain impact on the HR process in the upcoming Gig economy. Her passion of the area is in the 'Productivity of the Human Resources and their Performance Management with an extended interest in Cognitive Psychology. 